\title{
Main parameters influencing the plastic behavior of clays used for traditional ceramics production
}

\author{
Hicham Idrissi ${ }^{1,2,3^{*}}$, Lahcen Daoudi ${ }^{2}$, Jones Alami $^{1}$, Meriam El Ouahabi ${ }^{3}$, Nathalie Fagel ${ }^{3}$ \\ ${ }^{1}$ Material Sciences, Energy and Nano-Engineering department (MSN), Mohamed VI Polytechnic, Lot 660, Hay Moulay Rachid, 43150, \\ Benguérir-Morocco. \\ ${ }^{2}$ Laboratoire de Géosciences et Environnement (LGSE), Département de Géologie, Faculté des Sciences et Techniques, Université Cadi \\ Ayyad, BP 549, Marrakech, Morocco. \\ ${ }^{3}$ UR Argile, Géochimie et Environnement sédimentaires (AGEs), Département de Géologie, Quartier Agora, Bâtiment B18, Allée du six \\ Août, 14, Sart-Tilman, Université de Liège, B-4000, Belgium.
}

*Corresponding author: h.e.elidrissi@gmail.com

\begin{tabular}{|c|c|}
\hline Article Info & Abstract \\
\hline $\begin{array}{l}\text { Keywords: } \\
\text { Atterberg limits } \\
\text { Plasticity } \\
\text { Ceramic } \\
\text { Clay minerals } \\
\text { Morocco } \\
\text { Pottery }\end{array}$ & $\begin{array}{l}\text { This paper investigates the main parameters influencing the plastic behavior of clays } \\
\text { used for traditional ceramics production. For this, twenty-six clayey pastes were selected } \\
\text { from twelve traditional ceramic plants around the city of Marrakech (Morocco). } \\
\text { According to the lithology, six different types of materials are used as raw material in } \\
\text { the ceramic industry of this region. Emphasis is placed on the impact of the } \\
\text { characteristics of these clayey materials upon the plastic behavior of these clays. The } \\
\text { pastes were characterized through their consistency using the Atterberg limits. It has } \\
\text { been concluded that the gain size, the mineralogical and the clay mineral composition } \\
\text { and content, the effect of diagenesis and the presence of talc-pyrophyllite association } \\
\text { play the most important role in the control of the plasticity behavior. }\end{array}$ \\
\hline
\end{tabular}

\section{Introduction}

Plasticity is one of the most important parameters for manufacturing clayey ceramic products. It allows to ceramic paste to be easily workable during shaping process (Idrissi et al., 2021a). Several factors have been suggested in literature to be responsible for the plasticity behavior of soils and sediments. The knowledge of these factors leads to the optimization of the clay deposits used in local or regional ceramic industries (Idrissi et al., 2014, 2021b; Idrissi, 2017; El Ouahabi et al., 2019).

The plasticity level of an hydrated soil is mainly influenced by the clay mineralogy of the material, its particles distribution, the diagenesis level, the organic matter and the presence of amorphous clay-size materials (Hajjaji et al., 2010; Daoudi et al., 2014, 2015; Idrissi et al., 2014). This latter influences differently depending on its content and on the curing period in presence of water (Husein Malkawi et al., 1999). Generally, identifying the respective influences of all these parameters on the plasticity behaviour of the sedimentary material is difficult.

Research in this area has been traditionally focused on the influence of clay minerals on the plasticity properties of soil materials (Bain, 1971; Schmitz et al., 2004; Hajjaji et al., 2010; Idrissi et al., 2015). Dumbleton and West
(1966) studied the links between clay contents and the Atterberg consistency limits of natural soils around the world, trying to determine the contribution of the clay mineral to the engineering properties of soil. Kaolinite, chlorite and illite are considered as clays of low to moderate plasticity (Aiban, 2006)

Smectite clay rich soils are described in engineering as the most active and responsible for swelling problems, and are among the highest plastic clays (Low, 1980; Sridharan and Choudhury, 2002).

Fibrous clays (palygorskite and sepiolite) also manifest very high capacity for sorption (adsorption and absorption) (Galan, 1996) and then influence highly the plasticity behavior of soils. Their plasticity limit is even higher than that of smectite (Daoudi et al., 2015). The other clay species manifest low to moderate plasticity behavior.

The region of Marrakech, subject of this study is known for its geological variability (Idrissi et al., 2016) which consequently generates clay deposits of variable nature and then of variable plasticity. To adjust the properties of unfired ceramic body, some regional ceramic workshops mix different clayey materials. They generally mix coarser materials like schistose grains with finer soil to obtain the desired workability. 
Previous studies have discussed the link between the technological choices and other properties (Rye, 1981; Müller et al., 2013, 2014). In this study we will demonstrate that the technological choices for actual and archaeological ceramic materials have also a close link with the plasticity of the ceramic pastes. In this study, the contribution of each parameter on the plasticity behaviour of the ceramic pastes will be pointed. This study aims to present the plasticity behavior of several clay used in Marrakech ceramic industry and to evaluate the main parameters influencing it such as lithology, grain-size, and mineralogy.

\section{Studied area}

From a geomorphological point of view, the region of Marrakech comprises the north flank of High Atlas, the massifs of Jbilet and Rehamna, and the Haouz and Bahira plains. Briefly, on the geological side, the studied area displays a large sort of facies with ages allocated from Precambrian to Quaternary. In summary, twelve sites of traditional ceramics occur within a spread of 10 to $80 \mathrm{~km}$ round the city of Marrakech. Bouchane and Oulad Dlim sites are respectively located near the Paleozoic Rehamna and Jbilet massifs. Whereas Saada, Agafay, Tamsloht and Mzouda sites are located in the Haouz plain. The six other sites (Tamazouzt, Talatast, Ait Boussaid, Ourika, Amezmiz and Anougal) are located in the north flank of the High Atlas Mountain. A detailed description of the studied area and the studied materials can be found in Idrissi et al. (2018).

\section{Material}

The studied clay manifests various nature. Globally, we distinguish six forms of raw materials: Paleozoic schist, Quaternary soil, Mio-Pliocene and Triassic argillite and colluviums, washing sludges resulting from gravel pits and fine rivers sediments. In order to adjust the properties of both, the unfired ceramic body and the corresponding final product, the regional ceramic plants mix different clayey materials. Thus, the soil layers above the schist are generally mixed to them to improve the plasticity and to react as a binding agent. However, colluvium contains naturally, a significant quantity of plastic clay. Large choice of clays is present in Mzouda site, the potters try to mix the plastic raw material with the non-plastic one. The argillites show various degree of diagenesis from one site to another and this affect their plasticity degree (Idrissi et al., 2018).

In total, 26 pastes have been studied, they are used by the potters to manufacture different kind of products. The Table 1 resumes the details of each sample. The abbreviation used for samples nomenclature is based on the source area of each raw material. For the Saada site particularly, potters use the silty clays provided from different sources: Zaraba Canal (Zar), Wadi N'Fis (Nfs) and Wadi Tensift (Ten).

Table 1 : Nature and sources of pastes used to manufacture various products.

\begin{tabular}{|c|c|c|c|c|}
\hline Samples & Area & Lithology & Added materials & Color \\
\hline OD & Oulad Dlim & \multirow[b]{2}{*}{ Schist } & \multirow[b]{2}{*}{ Soil } & Brown \\
\hline $\begin{array}{l}\mathrm{Bo} 1 \\
\mathrm{Bo} 2\end{array}$ & Bouchane & & & Green \\
\hline $\mathrm{Nfs}$ & \multirow{3}{*}{ Saada } & \multirow{3}{*}{ Silty clays } & \multirow{6}{*}{ - } & \multirow{6}{*}{ Gray } \\
\hline Ten & & & & \\
\hline Zar & & & & \\
\hline $\mathrm{Ag} 1$ & Agafay & \multirow{3}{*}{ Soil } & & \\
\hline $\mathrm{Ag} 2$ & Agatay & & & \\
\hline Tms & Tamsloht & & & \\
\hline Mz1 & \multirow{6}{*}{ Mzouda } & Schist & \multirow{3}{*}{ Sand } & Yellow \\
\hline Mz2 & & Argillite & & Red \\
\hline $\mathrm{Mz3}$ & & Colluvium & & Orange \\
\hline $\mathrm{Mz} 4$ & & Argillite & \multirow[b]{2}{*}{ Silt } & Red \\
\hline Mz5 & & \multirow{2}{*}{ Schist } & & Gray \\
\hline Mz6 & & & - & Orange \\
\hline $\begin{array}{l}\text { Tmz1 } \\
\text { Tmz2 }\end{array}$ & Tamazouzt & Washing mud & - & Gray \\
\hline $\mathrm{Ta}$ & Talatast & Colluvium & - & Red \\
\hline $\mathrm{AB}$ & Ait Boussaid & \multirow[b]{2}{*}{ Argillite } & \multirow[b]{2}{*}{-} & Brown \\
\hline $\begin{array}{l}\text { Our1 } \\
\text { Our2 }\end{array}$ & \multirow{4}{*}{ Ourika } & & & Red \\
\hline Our3 & & Schist & - & Green \\
\hline Our4 & & Colluvium & Silty clays & Brown \\
\hline Our5 & & Argillite & Colluvium & Red \\
\hline $\mathrm{Am}$ & Amezmiz & \multirow{2}{*}{ Schist } & Soil & Brown \\
\hline An & Anougal & & - & Orange \\
\hline
\end{tabular}




\section{Methods}

The used methods for X-ray diffraction, X-ray fluorescence spectroscopy and particles size distribution are described in Idrissi et al., (2018). The Atterberg limits was carried out on the fraction of the material passing through the $425 \mu$ sieve. The required weight is about $150 \mathrm{~g}$ of the undersize of this sieve.

\section{Liquid limit}

The measurement of the liquid limit was executed by a Casagrande apparatus based on the method of Atterberg. The operation consists in spreading a liquid paste in a container so as to obtain a layer of about $1 \mathrm{~cm}$ thick in the middle.

The paste is grooved in the cup so as to divide it into two equal parts separated by a V-shaped groove having at bottom of the cup exactly $2 \mathrm{~mm}$ wide. The cup is then dropped onto the base by actuating the crank at the rate of 2 strokes per second until the groove is closed over a length of $10 \mathrm{~mm}$. We count the number of blows required to cause the groove in the clay bed (Méthode de Mesure, 1981).

The number of shocks required for closing is noted and about $10 \mathrm{~g}$ are sampled in the area where the groove has closed to measure the water content of the paste. The number of shocks must be between 15 and 35 for the measurement to be valid. The operation is repeated on the same paste after retracing the groove to check if the number of strokes remains the same, otherwise it is necessary to knead the paste again on the cup and repeat the operation.

It is necessary to cumulate at least three tests (number of shocks with the corresponding water contents) in order to draw up a curve which makes it possible to deduce the liquidity limit which is the water content corresponding to 25 shocks.

\section{Plastic limit}

The plastic limit is determined by rolling a small ball of semi-soft paste (which does not stick to the fingers) to form a clay coil 10-15 cm in length and $3 \mathrm{~mm}$ in diameter. After obtaining the clay coil, we put it back into a ball and repeat the coiling clay procedure. The operation is repeated until the paste breaks during winding before reaching $3 \mathrm{~mm}$ in diameter. At this time, the coil clay is weighed on a small beaker of known mass to calculate the wet mass (Mw). The sample is placed in an oven for 24 hours at 105 ${ }^{\circ} \mathrm{C}$ in order to deduce the dry mass $(\mathrm{Md})$. The water content $(\% \mathrm{~W})$ is calculated relative to the dry mass with the equation 1 :

$$
\% \boldsymbol{W}=\frac{(\boldsymbol{M w}-\boldsymbol{M d}) \times \mathbf{1 0 0}}{\boldsymbol{M d}} \quad \text { Eq. } 1
$$

The same operation is repeated on another coil clay. The difference between the two water content values should not be more than $1 \%$. And we take the arithmetic mean of these two values as the plastic limit.

\section{Plasticity index}

The plasticity index was measured through the Atterberg limits using the equation 2:

$$
\boldsymbol{P I}=\boldsymbol{L} \boldsymbol{L}-\boldsymbol{P} \boldsymbol{L} \quad \text { Eq. } 2
$$

Where: PI is the plasticity index, LL is the liquid limit and PL is the plastic limit.

\section{Results and Discussion}

\section{Plastic behaviour}

Plasticity is mainly influenced by the mineralogy of the material, but also by the sand, silt and clay fraction. These latter exhibit a wide range of engineering characteristics. To make terms more useful in engineering practice, the Casagrande's plasticity chart classifies clayey and silty soils according to their behaviour (Holtz and Kovacs, 1981).

The results for consistency limits (i.e., plastic limit [PL], liquid limit [LL]) of the studied samples, and the plasticity indexes (PI) are shown in Table 2. The studied samples are plotted in various areas on the 'Liquid LimitPlasticity Index' Chart (Figure 1), meaning that these pastes tend to have different engineering behavior. In fact, Holtz and Kovacs (1981) consider that soils in which fine grains do control the engineering behavior are classified according to their plasticity characteristics. Plasticity, swelling capacity and organic matter content are taking a part in this classification (Figure 1). The A-line generally separates the more claylike materials from those that are silty and also the organics from the inorganics. Almost all studied samples are above the A-line, but they have low to high values of plasticity and swelling (32\% < LL < 55\%) as indicated in the top of the diagram.

The Plasticity index (PI) indicates the presence of two main groups of pastes. The first group is characterized by PI values ranging between 15 and 20. This group comprises principally the pastes composed of schist, washing muds, silty clays and soil. In this group, we can see that the plasticity index and the liquid limit of schist are the lowest $(\mathrm{LL} \leq 37 \%)$. A low liquid limit means that the content of retained water is low, so the paste is less plastic and more stable. For the second group, the PI ranges between 21 and 32. This group comprises principally the pastes composed of colluvium and argillite. All pastes made by colluviums are characterized by high PI (25-27). 
The result in Figure 2 reveals that almost all investigated pastes are plotted inside the optimal moulding region, except Ten, Nfs and Our5 that are located inside the acceptable area, while the other are located outside both the acceptable and optimum moulding regions.
Furthermore, most sample could exhibit low shrinkage due to the fact that their plastic limits are relatively low and consequently imply less colloidal and intergranular water responsible of shrinkage.

Table 2: Particle size distribution and consistency limits (\%) of the studied samples.

\begin{tabular}{|c|c|c|c|c|c|c|c|}
\hline \multirow[b]{2}{*}{ Lithology } & \multirow[b]{2}{*}{ Samples } & \multicolumn{2}{|c|}{ Consistency limits (\%) } & \multirow{2}{*}{$\begin{array}{c}\text { Plasticity } \\
\text { indexes (PI) }\end{array}$} & \multicolumn{3}{|c|}{ Particle size distribution (\%) } \\
\hline & & $\begin{array}{l}\text { Liquid limit } \\
\text { (LL) }\end{array}$ & $\begin{array}{l}\text { Plastic limit } \\
(\mathrm{PL})\end{array}$ & & $\begin{array}{l}\text { Clay fraction } \\
(<2 \mu \mathrm{m})\end{array}$ & $\begin{array}{c}\text { Silt fraction } \\
(2-20 \mu \mathrm{m})\end{array}$ & $\begin{array}{l}\text { Sand fraction } \\
(>20 \mu \mathrm{m})\end{array}$ \\
\hline \multirow[t]{9}{*}{ Schist } & Bo1 & 34 & 19 & 15 & 18 & 26 & 56 \\
\hline & Bo2 & 35 & 19 & 16 & 20 & 27 & 53 \\
\hline & OD & 36 & 21 & 15 & 25 & 23 & 52 \\
\hline & Am & 37 & 19 & 18 & 19 & 25 & 56 \\
\hline & An & 36 & 19 & 17 & 18 & 22 & 60 \\
\hline & Our3 & 35 & 18 & 17 & 23 & 12 & 65 \\
\hline & Mz1 & 34 & 17 & 16 & 20 & 26 & 54 \\
\hline & Mz5 & 33 & 15 & 18 & 19 & 39 & 42 \\
\hline & Mz6 & 32 & 16 & 16 & 30 & 27 & 43 \\
\hline \multirow{3}{*}{ Wadi sediment } & Nfs & 48 & 32 & 16 & 34 & 34 & 32 \\
\hline & Ten & 47 & 30 & 17 & 40 & 53 & 7 \\
\hline & Zar & 48 & 24 & 24 & 62 & 33 & 5 \\
\hline \multirow[t]{3}{*}{ Soil } & Ag1 & 38 & 21 & 16 & 50 & 35 & 15 \\
\hline & Ag2 & 39 & 21 & 16 & 51 & 28 & 21 \\
\hline & Tms & 45 & 25 & 20 & 34 & 43 & 23 \\
\hline \multirow[t]{6}{*}{ Argillite } & Mz2 & 34 & 17 & 17 & 38 & 17 & 45 \\
\hline & Mz4 & 37 & 19 & 18 & 40 & 35 & 25 \\
\hline & $\mathrm{AB}$ & 40 & 22 & 18 & 27 & 12 & 61 \\
\hline & Our1 & 52 & 22 & 30 & 66 & 25 & 9 \\
\hline & Our2 & 40 & 19 & 21 & 48 & 30 & 22 \\
\hline & Our5 & 55 & 23 & 32 & 41 & 31 & 28 \\
\hline \multirow[t]{3}{*}{ Colluvium } & Mz3 & 43 & 18 & 26 & 25 & 34 & 41 \\
\hline & $\mathrm{Ta}$ & 49 & 24 & 25 & 26 & 26 & 48 \\
\hline & Our4 & 46 & 19 & 27 & 36 & 27 & 37 \\
\hline \multirow[t]{2}{*}{ Washing sludges } & Tmz1 & 39 & 23 & 16 & 60 & 22 & 18 \\
\hline & Tmz2 & 39 & 24 & 15 & 64 & 24 & 12 \\
\hline
\end{tabular}

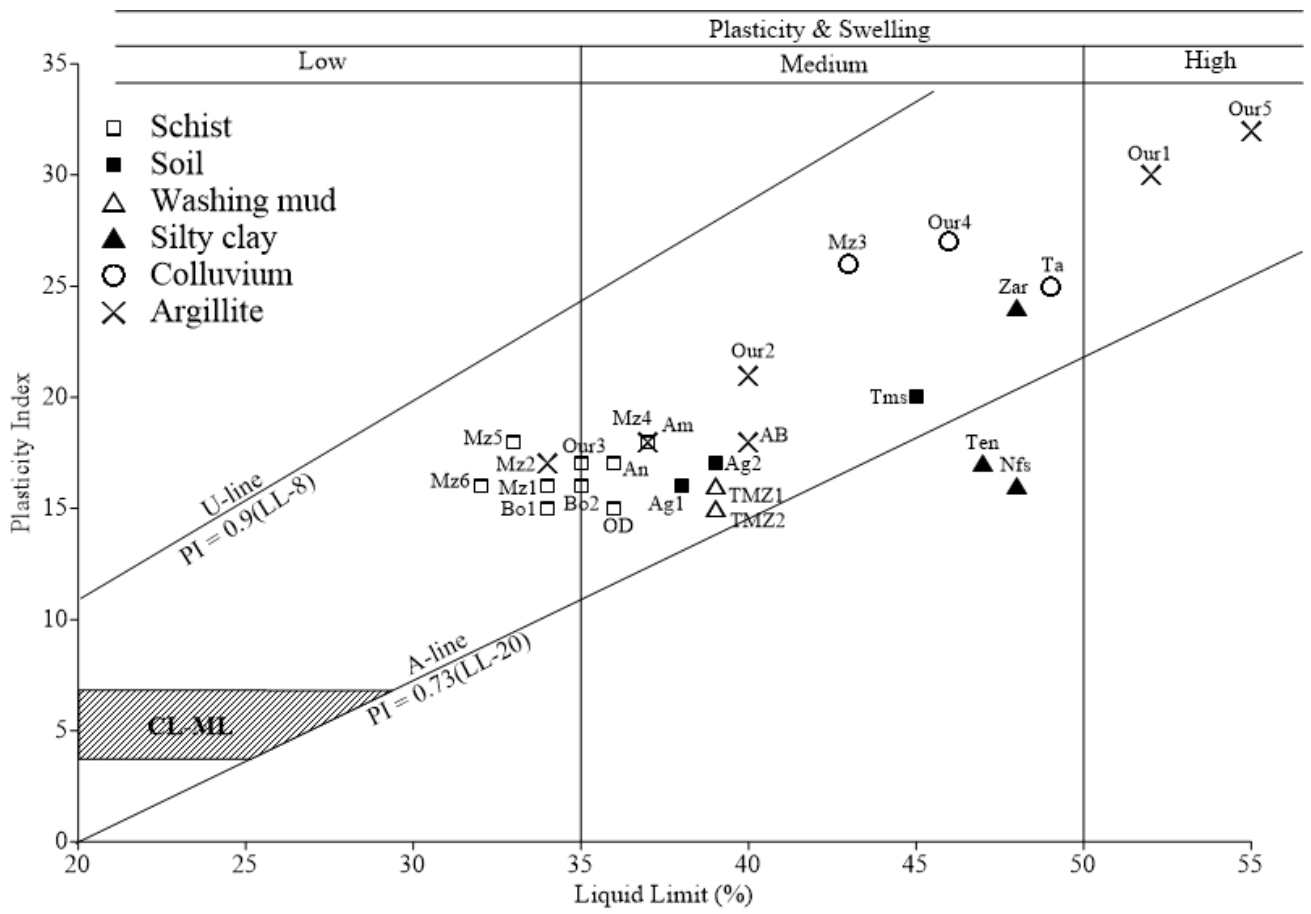

Figure 1: Plotted samples on Casagrande Chart (Casagrande, 1948) [after Howard (1977) and Dakshanamurthy and Raman (1973)]. CL: Clay of Low liquid limit. ML: Silt of Low liquid limit. 


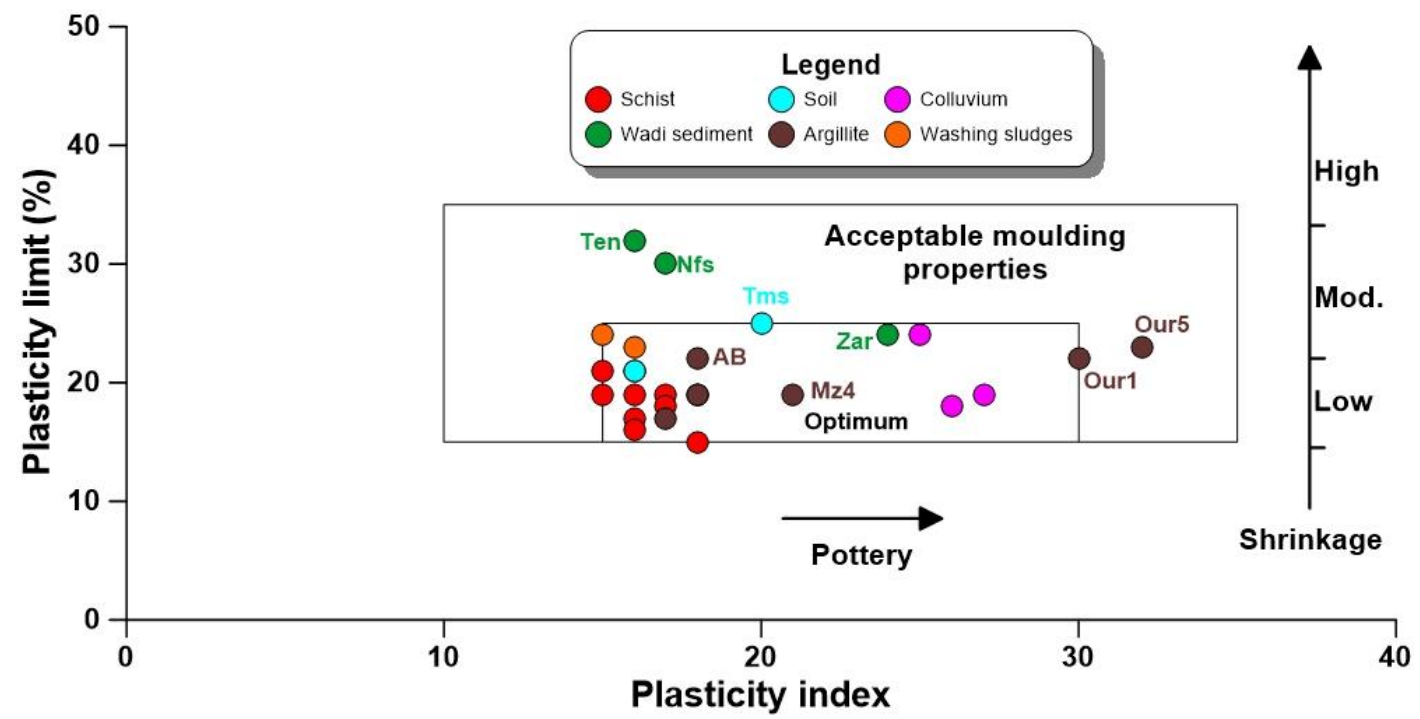

Figure 2: Studied pastes workability through the Atterberg limits (Bain and Highly, 1978).

\section{Impact of particle size distribution on the plasticity}

The particle size distribution results of the studied samples are listed in Table 2. They show wide variation, having clay fraction $(<2 \mu \mathrm{m})$ from 18 to $66 \%$, silt fraction from 12 to $53 \%$ and sand fraction from 5 to $65 \%$. In order to understand the influence of particle size distribution on plasticity, we first projected the studied pastes on the Shepard classification diagram (1954) following the relation between sand, silt, and clay (Figure 3). The samples generally plot in the sand-silt-clay, silty sand, silty clay and clayey sand fields. Schist samples have relatively more sandy composition, whereas washing muds, silty clays and soils are relatively more clayey. Samples composed of argillite are characterized by wide variation in particle size and are plotted in various fields on Shepard's diagram. The Shepard's classification does not consider the type of sediment and its origin. The Unified Soil Classification System developed by Casagrande (1948) considers that materials in which silts and clays do not affect the engineering performance are classified according to their grain size characteristics.

The studied samples were previously plotted on the McManus Diagram (2018) to show their degree of permeability and porosity. It has been noticed in that previous study that most of the studied samples have a low porosity and permeability which allow them to have good workability due to the good cohesion between particles. And even the plastic properties of coarse pastes could be improved by better crushing process.

The results obtained in Figure 4 show that there is no obvious relationship between the clay fraction content of the studied sample and their plasticity behavior; samples with approximately the same clay fraction content can display very different plasticity indexes and reversely which is normal because the correlation coefficient is very low $(\mathrm{COR}[\mathrm{X}, \mathrm{Y}]=0.25)$. Furthermore, the Shepard diagram shows that the pastes based on schist and colluviums have relatively the same grain size composition; they are characterized by coarser materials, however, while the former displays the lowest plasticity, the second have medium to high plasticity. the mineralogical data are crucial to explain these behaviors.

\section{Impact of mineralogical composition on the plasticity}

\section{Whole rock composition}

The mineral composition of the bulk-samples consists mainly of clay minerals, quartz, feldspar, hematite and carbonate (calcite and dolomite). Quartz and feldspar are ubiquitous with a proportion varying between 20 to $55 \mathrm{wt}$. $\%$ and 5 to $35 \mathrm{wt}$. \% respectively. Hematite is present in minor amounts in most of the samples (0-10 wt. \%). The total carbonate (calcite + dolomite) ranges between 0 and 15 wt. \%. The clay minerals content ranges between 25 and 60 wt. \%. During the shaping phase, clay minerals act as plastic and binder components, while other silicates and carbonates as skeletal components.

\section{Clays composition and plasticity}

The mineralogical data of whole-rock are not sufficient alone to explain the plasticity behavior and the clay minerals composition is necessary. In fact, this latter is fundamental to the understanding of engineering behavior of fine-grained soils.

The clay minerals of the studied paste in the fraction < $2 \mu \mathrm{m}$ are diversified. They are made by a mixture of illite (10-40\%), kaolinite (5-15\%), smectite, mixed layers $(<10 \%)$, vermiculite and chlorite $(<5 \%)$, pyrophyllite-talc association $(5-10 \%)$ is present in the samples Our1, Our2, Our4, Our5 and Tms. Fibrous clay is only present in one paste (Ta), with a content of $18 \%$. 


\section{Clay fraction-total clay duality}

The fraction $<2 \mu \mathrm{m}$ could include clay minerals and very fine non-clay minerals. Total clay designates all clay minerals even if their size exceeds $2 \mu \mathrm{m}$. The Figure 5 depicts the clays mineralogy and the clay fraction rate of the whole of studied pastes, with an indication of their lithological nature and of their $\mathrm{CF} / \mathrm{TC}$ ratio. This figure includes the mineralogical parameter of clays in order to explain the decorrelation highlighted previously between the grain-size and the plasticity. In fact, the pastes with plasticity indexes $\geq$ to 24 are composed of significant content of smectite, fibrous clay and "smectite + talcpyrophyllite" association. The content of smectite could not have great impact if the clay fraction is very low $(<20$ $\%)$. More discussion about the difference between the total clay and the clay fraction is to find in Idrissi et al. (2018).

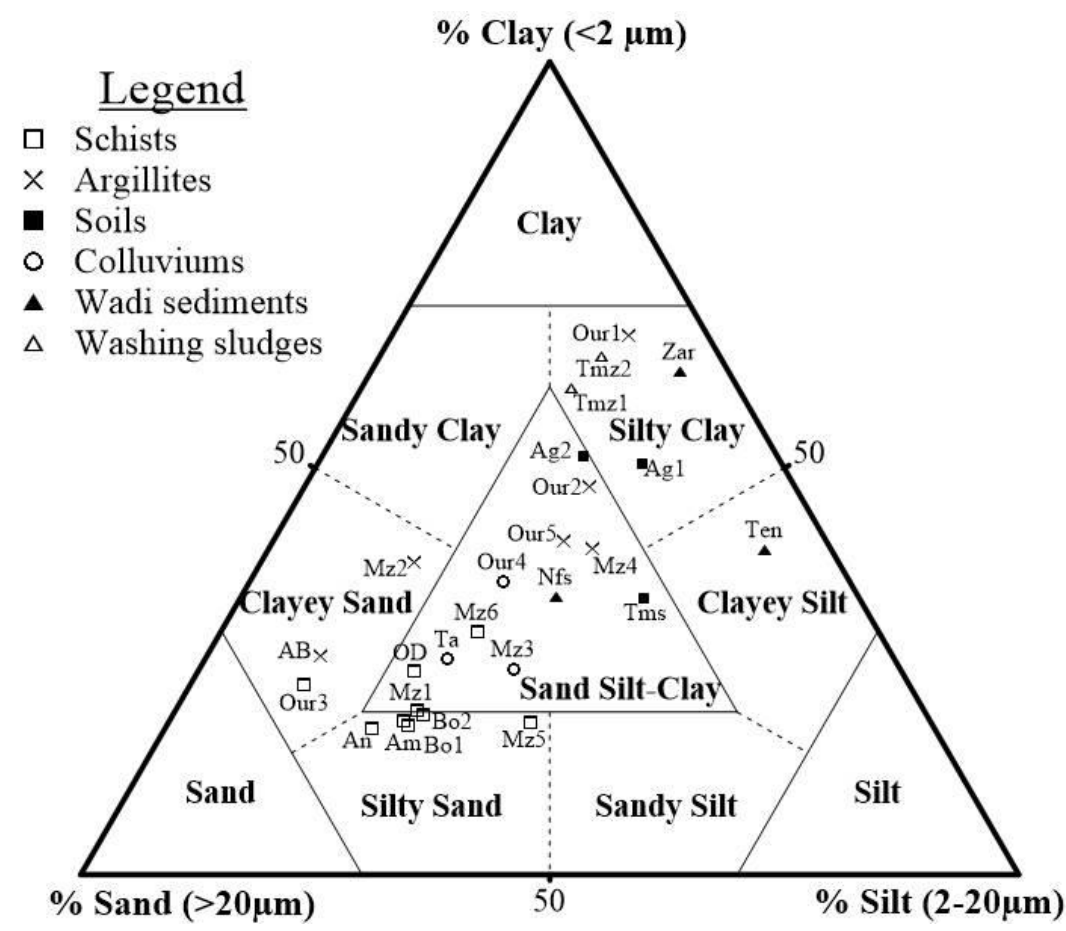

Figure 3: Classification of studied clay raw materials based on the sand-silt-clay ratios (Shepard, 1954).

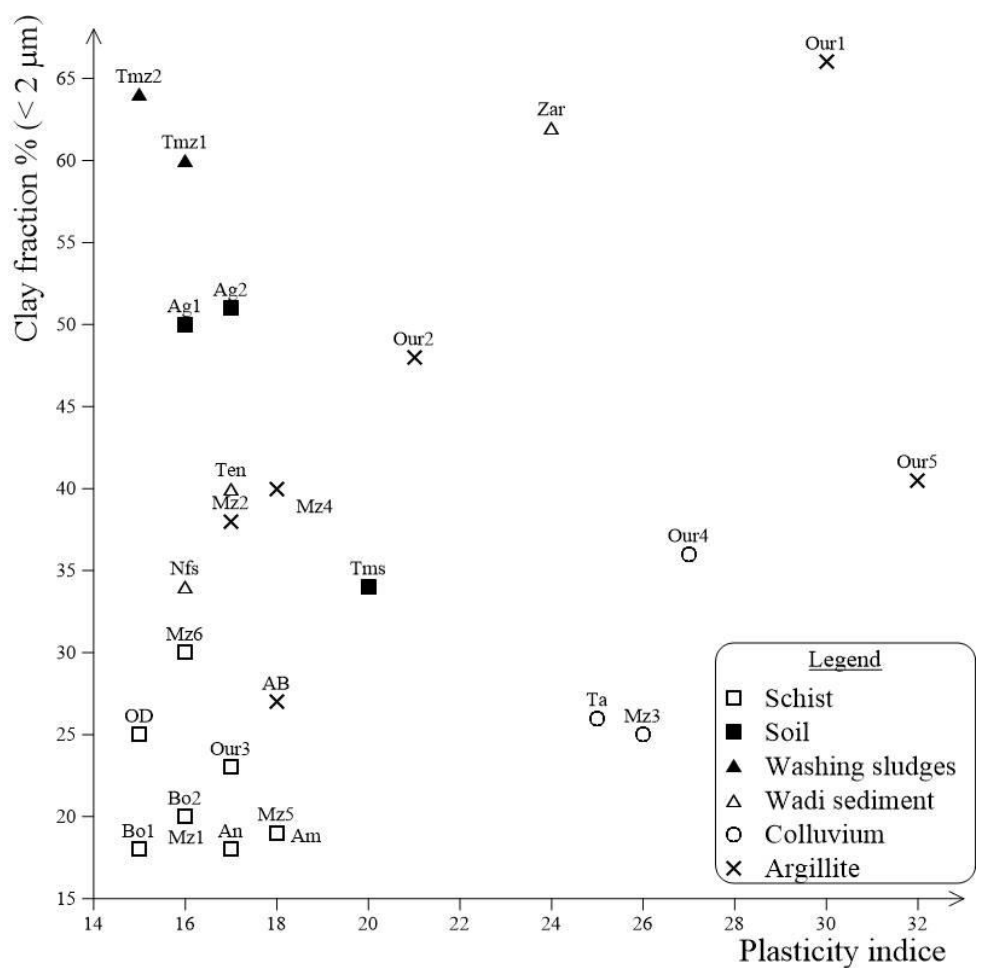

Figure 4: The plasticity indices of the samples studied as a function of the percentage of the fraction $<2$ microns $(\mathrm{COR}[\mathrm{X}, \mathrm{Y}]=0.25)$. 


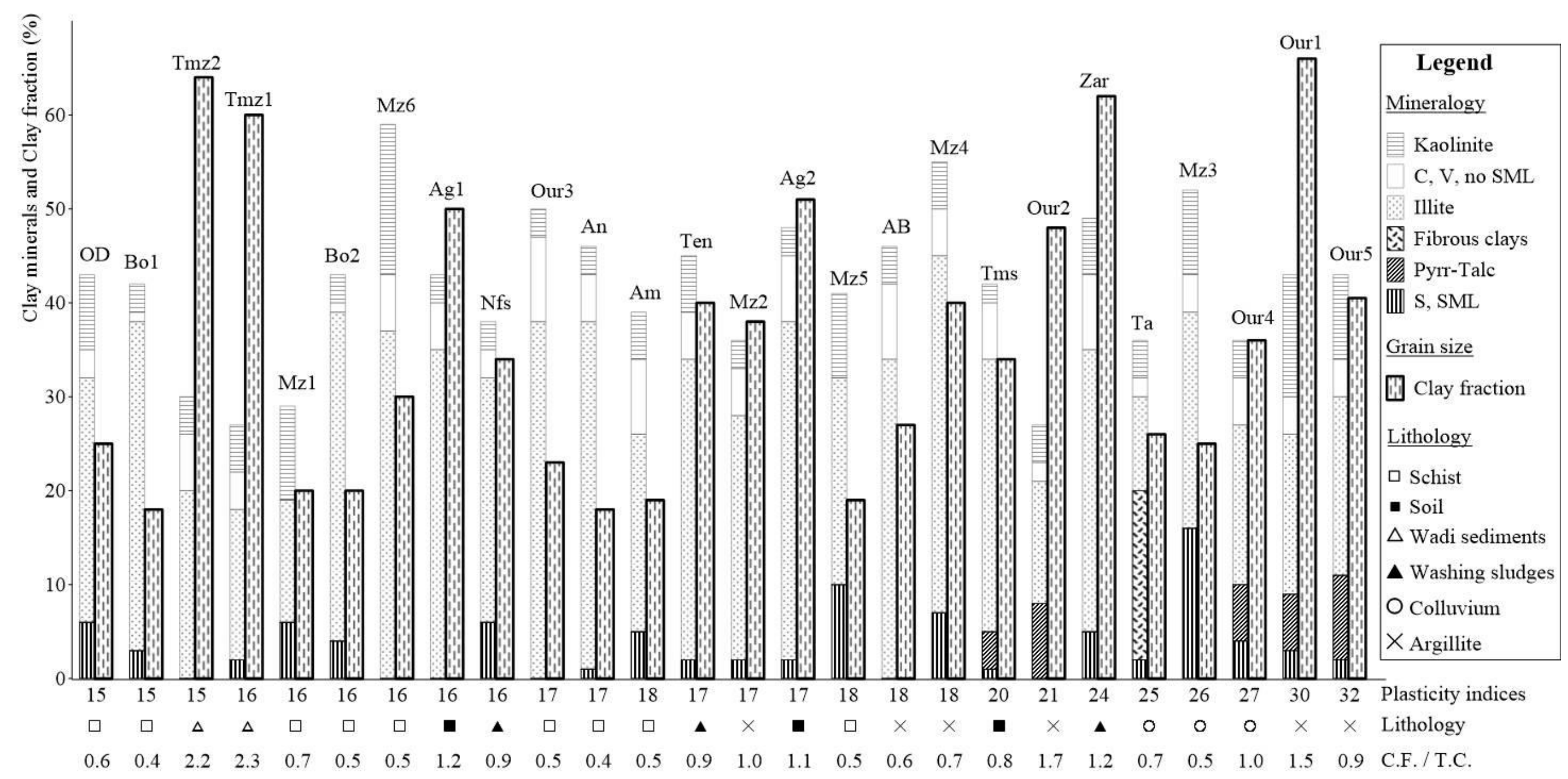

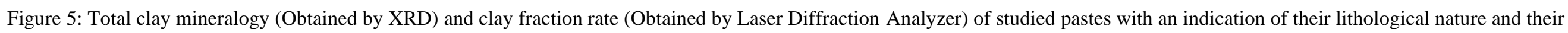
clay fraction / total clay ratio (CF/TC). 
Daoudi et al. (2010) show that the burial diagenesis is the main factor controlling the genesis of the clay assemblages of the sedimentary series of the Lower Mesozoic of the Western High Atlas. The effects of burial on these clay assemblages are expressed as the downward increase in the proportions and size of the illite crystallites. In addition, depending on their granulometry, mineralogical and chemical composition, argillites represent the most heterogeneous materials studied. They belong to different sedimentary series which have undergone varying degrees of diagenesis and this has affected their degree of plasticity. The plasticity indices of the argillites are distributed between two extreme poles: clay of low plasticity and clay of high plasticity (Figure 5) and their "clay fraction/total clay (CF/TC)" ratios are between 0.7 and 1, 7. This suggests that the effect of diagenesis seems to have played a major role in the behavior of the plasticity of these materials.

In addition, the observations in scanning electron microscopy show that the Bouchane paste based on shale has illite particles with large sizes (> $20 \mu \mathrm{m}$; Figure 6). This explains the low clay fraction / total clay ratio in the case of shale-based pulps (Figure 5).

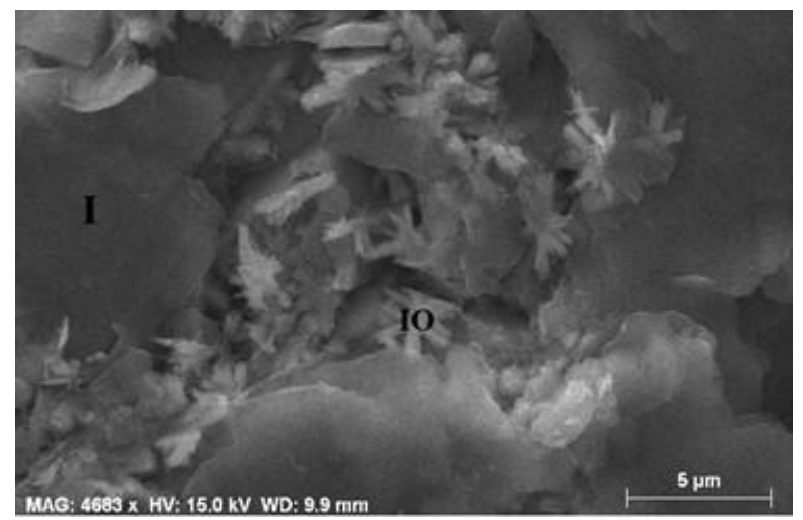

Figure 6: SEM micrographs of schistose fabrics from

Bouchane showing the large particles of illite (I) with a grain-size $>$ to $5 \mu \mathrm{m}$.

The difference in the plasticity behavior between pastes based on schist $(\mathrm{PI} \leq 18)$ and on colluvium $(25 \leq \mathrm{PI} \leq 27)$, despite the similarity expressed by their coarser grain-size distribution, can be explained by their clay composition. Indeed, in most schist samples, the clay composition is dominated by the illite and the kaolinite which are considered as clays of low plasticity. Whereas the colluviums are characterized by a high content of some specific clays: fibrous clays [Ta], pyrophyllite-talc association [Our4], smectite and smectitic mixed layers [Ta, Our4 and Mz3].

\section{The most influential minerals on plasticity}

It is well known that the smectites and the fibrous clays display the highest plasticity behavior of clays; this explains the high plasticity indexes of samples Mz3 (PI = 26) and $\mathrm{Ta}(\mathrm{PI}=25)$. For the third paste made by colluvium (Our4) as well as in other pastes made by argillite (Our1 and Our5), and soil (Tms), the clay composition is characterized by low amount of smectite, but coupled with a variable amount of the talcpyrophyllite association which result from the dismantling of metamorphic rocks of Paleozoic and Triassic (Daoudi and Pot De Vin, 2002). The talc has good ceramic properties. It is an ideal complement to ball clay (clay of high plasticity) to create a dryable body that still has excellent working properties with a good feeling in the hands of the artisan. Talc and Pyrophyllite are close to the smectite in structure and chemical composition, but behave very differently from smectite (Giese et al., 1991). The former are hydrophobic (Steenberg and Harris, 1985) while the latter is hydrophilic. Thus, talc and pyrophyllite are not able to intercalate water and swell due to the relatively weak interaction between the surfaces 001 of these two minerals and water molecules (Giese et al., 1991). Consequently, talc powder has a low plasticity (Norsker, 1990). But these hydrophobic minerals are known to possess a weak van der Waals bond giving them the property of dispersing easily in water and keep them from clumping (Mukherjee, 2013). This author explains that with such dispersing minerals (anti caking), other clays are being dispersed and then easily dissolved in water without clumping. Thus, a greater surface area of the clays will be made available to react with water and to increase the amount of water absorbed by smectite. This explains why the plasticity indexes are the highest in samples with the couple of talc-pyrophyllite and smectite. The highest plasticity indexes are identified in the pastes based on argillites from Ourika site (pastes Our1 and Our5). This high plasticity allows to artisans of Ourika site to produce the most complicated decoration forms at the region of Marrakech (Fig. 2f). These samples are characterized by: a high rate of clay fraction (66 and $41 \%$ respectively), a high total clay content $(41 \%)$ and the presence of the pyrophyllite-talc and smectite association.

The plasticity indexes of soils are not very different from those of schist except for the paste of Tamsloht which contains the pyrophyllite-talc association and reaches a PI of 20. The PI of washing muds is still low despite the high rate of clay fraction. This is due to the low content in total clay $(<28 \%)$.

\section{Conclusion}

This study shows as expected, in most of the studied samples, there is a clear relationship between the plasticity behaviour in one hand and the grain size distribution, clay content and clay mineral composition in the other hand. Fine grain-sized materials as well as those containing smectite and fibrous clays display the most plastic 
behaviour, whereas the pastes with coarser grain-size associated with the presence of illite display the lowest plasticity. Adding that despite its low plasticity, the talcpyrophyllite association can display the highest plasticity indexes when coupled with smectite in the same materials. However, in some categories of samples (argillites), the plasticity can be influenced by the effect of diagenesis.

\section{Acknowledgments}

The authors would like to thank the ArGEnCo Laboratory (University of liege) for its support in carrying out the Atterberg limit tests, and especially professor Frédéric Collin.

\section{References}

Aiban, S.A., 2006. Compressibility and swelling characteristics of AlKhobar Palygorskite, eastern Saudi Arabia. Eng. Geol. 87, 205-219. https://doi.org/10.1016/j.enggeo.2006.07.003

Bain, J.A., 1971. A plasticity chart as an aid to the identification and assessment of industrial clays. Clay Miner. 9, 1-17.

Bain, J.A., Highly, D.E., 1978. Regional appraisal of clay resources challenge to the clay mineralogist. In: Mort- land M.M. \& Farmer V.C. (eds), Proc. Int. Clay Conference, Elsevier, Amsterdam 437-446.

Casagrande, A., 1948. Classification and Identification of Soils. Trans. Am. Soc. Civ. Eng. 113, 901-930.

Dakshanamurthy, V., Raman, V., 1973. A simple method of identifying an expansive soil. Soils Found. 13, 97-104.

Daoudi, L., El boudour El Idrissi, H., Saadi, L., Albizane, A., Bennazha, J., Waqif, M., El Ouahabi, M., Fagel, N., Idrissi, H.E. boudour El, Latifa, S., Abderrahmane, A., Jamal, B., Mohamed, W., Meriam, E., Nathalie, F., 2014. Characteristics and ceramic properties of clayey materials from Amezmiz region (Western High Atlas, Morocco). Appl. Clay Sci. 102, 139-147. https://doi.org/10.1016/j.clay.2014.09.029

Daoudi, L., Knidiri, A., El Boudour El Idrissi, H., Rhouta, B., Fagel, N., 2015. Role of the texture of fibrous clay minerals in the plasticity behavior of host materials (Plateau du Kik, Western High Atlas, Morocco). Appl. Clay Sci. 118, 283-289. https://doi.org/10.1016/j.clay.2015.10.006

Daoudi, L., Ouajhain, B., Rocha, F., Rhouta, B., Fagel, N., Chafiki, D., 2010. Comparative influence of burial depth on the clay mineral assemblage of the Agadir-Essaouira basin (western High Atlas, Morocco). Clay Miner. 45, 453-467.

Daoudi, L., Pot De Vin, J., 2002. Effets thermique et hydrothermal de la coulée de basalte triasico-liasique sur les argiles du bassin d'Argana ( Maroc ). Comptes Rendus Géoscience 334, 463-468.

Dumbleton, M.J., West, G., 1966. Some factors affecting the relation between the clay minerals in soils and their plasticity. Clay Miner. 6, 179-193.

El Boudour El Idrissi, H., Daoudi, L., El Ouahabi, M., Collin, F., Fagel, N., 2014. Utilisation des résidus de lavage des granulats de carrières dans l'élaborationde pièces céramiques (Région de Tamazouzt, Maroc).

El Boudour El Idrissi, H., Daoudi, L., Fontaine, F., Collin, F., Fagel, N., 2015. Identification of the main parameters controlling the plasticity of ceramic pastes: The case study of the Marrakech region (Morocco).

El Ouahabi, M., El Boudour El Idrissi, H., Daoudi, L., El Halim, M., Fagel, N., 2019. Moroccan clay deposits: Physico-chemical properties in view of provenance studies on ancient ceramics. Appl. Clay Sci. 172, 6574. https://doi.org/10.1016/j.clay.2019.02.019

Galan, E., 1996. Properties and applications of palygorskite-sepiolite clays. Clay Miner. 31, 443-453.
Giese, R., Costanzo, P., Oss, C. Van, 1991. The surface free energies of talc and pyrophyllite. Phys. Chem. Miner. 17, 611-616.

Hajjaji, W., Hachani, M., Moussi, B., Jeridi, K., Medhioub, M., LópezGalindo, a., Rocha, F., Labrincha, J. a., Jamoussi, F., 2010. Mineralogy and plasticity in clay sediments from north-east Tunisia. J. African Earth Sci. 57, 41-46. https://doi.org/10.1016/j.jafrearsci.2009.07.007

Holtz, R.D., Kovacs, W.D., 1981. An Introduction to Geotechnical Engineering 747.

Howard, A.K., 1977. Laboratory Classification of Soils: Unified Soil Classification System. US Department of the Interior, Bureau of Reclamation, Engineering and Research Center, Division of Research, Geotechnical Branch.

Husein Malkawi, A.I., Alawneh, A.S., Abu-Safaqah, O.T., 1999. Effects of organic matter on the physical and the physicochemical properties of an illitic soil. Appl. Clay Sci. 14, 257-278. https://doi.org/10.1016/S0169-1317(99)00003-4

Idrissi, H.E.B. El, 2017. Characterization of clays used in the earthenware sector of Marrakech region to improve the quality of the products. UCA in partenership with ULiege.

Idrissi, H.E.B. El, Daoudi, L., Collin, F., Fagel, N., 2014. Caractérisation de colluvions triasiques utilisés dans l'élaboration d'ustensiles rustiques de cuisson, cas de Talatast (Région de Marrakech, Maroc). Verres, Céramiques Compos. 3, 18-22.

Idrissi, H.E.B. El, Daoudi, L., El Ouahabi, M., Balo Madi, A., Collin, F., Fagel, N., 2016. Suitability of soils and river deposits from Marrakech for the manufacturing of earthenware. Appl. Clay Sci. 129, 108-115. https://doi.org/10.1016/j.clay.2016.05.013

Idrissi, H.E.B. El, Daoudi, L., Ouahabi, M. El, Collin, F., Fagel, N., 2018. The influence of clay composition and lithology on the industrial potential of earthenware. Constr. Build. Mater. 172, 650-659. https://doi.org/10.1016/j.conbuildmat.2018.04.019

Idrissi, H., Borja, W., Fagel, N., Daoudi, L., 2021a. Simple approach to elaborate test bricks for traditional ceramic studies 1. https://doi.org/10.20944/preprints202101.0257.v1

Idrissi, H., Taha, Y., Elghali, A., El Khessaimi, Y., Aboulayt, A., Amalik, J., Hakkou, R., Benzaazoua, M., 2021b. Sustainable use of phosphate waste rocks: From characterization to potential applications. Mater. $\begin{array}{llll}\text { Chem. } & \text { Phys. } & 260, & 12419 .\end{array}$ https://doi.org/10.1016/j.matchemphys.2020.124119

Low, P.F., 1980. The Swelling of Clay: II. Montmorillonites1. Soil Sci. $\begin{array}{lllll}\text { Soc. Am. } & \text { J. }\end{array}$ https://doi.org/10.2136/sssaj1980.03615995004400040001x

Méthode de Mesure, C.R.R., 1981. Mode opératoire, Limites de consistance des sols (limites de liquidité et de plasticité). Cent. Rech. Routières MF47/81, 41.

Mukherjee, S., 2013. The Science of Clays: Applications in Industry, Engineering, and Environment. Springer Science \& Business Media.

Müller, N.S., Hein, A., Kilikoglou, V., Day, P.M., 2013. Bronze Age cooking pots: Thermal properties and cooking methods. Préhistoires Méditerranéennes.

Müller, N.S., Kilikoglou, V., Day, P.M., Vekinis, G., 2014. Thermal shock resistance of tempered archaeological ceramics. M MartinónTorres (Ed.), Cr. Sci. Int. Perspect. Archaeol. Ceram. Doha, Qatar Bloom. Qatar Found. https://doi.org/http://dx.doi.org/10.5339/uclq.2014.cas.ch28 Norsker, H., 1990. Clay materials for the self-reliant potter.

Rye, O.S., 1981. Pottery technology: principles and reconstruction. Schmitz, R.M., Schroeder, C., Charlier, R., 2004. Chemo-mechanical interactions in clay: A correlation between clay mineralogy and Atterberg limits. Appl. Clay Sci. 26, 351-358. https://doi.org/10.1016/j.clay.2003.12.015

Shepard, F.P., 1954. Nomenclature based on sand-silt-clay ratios. J. Sediment. Res. 24, 151-158.

Sridharan, A., Choudhury, D., 2002. Swelling pressure of sodium montmorillonites. Géotechnique 52, 459-462. https://doi.org/10.1680/geot.2002.52.6.459

Steenberg, E., Harris, P.J., 1985. Surface-chemical and mineralogical properties relevant to the flotation of talc and other layer silicates. 